\title{
When Surfing Meets Surgery: Using Off-The-Shelf Action Cameras to Create a Wireless, Portable, HD Point-Of-View Surgical Recording System without Breaking the Bank
}

\author{
Andrew Thompson ${ }^{1}$, Kevin Warrian ${ }^{2}$, Karim Punja ${ }^{2}$, Adrian Gooi ${ }^{3}$, Patrick Gooi ${ }^{2}$ \\ ${ }^{1}$ Department of Neuroscience, University of Calgary, Canada \\ ${ }^{2}$ Department of Surgery, University of Calgary, Canada \\ ${ }^{3}$ Department of Otolaryngology - Head \& Neck Surgery, University of Manitoba, Manitoba, Canada
}

Submission: October 02. 2017; Published: November 13, 2017

*Corresponding author: Patrick Gooi, Cloudbreak Eye Care, Suite 315-5340 1st ST SW, Calgary, Alberta T2H0C8, Tel: 403-281-0603;

Fax: 403-281-2471; Email: patrick.gooi@cloudbreak.ca

Abstract

There is increasing interest in adapting point-of-view (POV) action cameras for medical education, especially in surgery. Although these consumer POV action cameras are considerably cost effective compared to other methods of recording surgery, they are limited by battery life and storage capacity. We innovatively combined a number of consumer products to create a cost-effective, wireless HD POV recording system that is scalable and portable.

Keywords: Medical education; Point-of-view camera; Surgery

\section{Introduction}

There is interest in adapting consumer, point-of-view (POV) action cameras for medical education. We have previously reported on using POV cameras for studying surgical ergonomics [1], scleral buckle surgery [2], as well as a dual camera system [3]. However, consumer POV cameras off the shelf have a number of limitations. There is limited battery life and storage capacity. There is also difficulty in transmitting a live video feed in high definition. Faced with this conundrum, we combined semispecialized consumer equipment to evaluate a wireless, point of view HD surgical video recording system that overcomes many of these challenges

\section{Methods}

The surgeon's kit comprises a POV camera with an HD wired output (GoPro, San Mateo, CA), which is fed to a wireless HD transmission system (NYRIUS, Niagara Falls, ON). Both the camera and transmission system are powered by a portable USB power source, commonly used to charge mobile devices. The POV camera can be either mounted on the head for sterile procedures, or chest-mounted for clean procedures. The wireless transmitter and USB power source can be carried in the surgeon's pocket.
The recording station comprises the wireless HD receiver (NYRIUS, Niagara Falls, ON) which receives the live HD video feed from the camera. This feed is directed to an HD capture system (Elgato, San Francisco, CA), which records the footage on the connected laptop's hard drive. The cost of the entire system is under \$2000 USD (Table 1) and an instructional video for setup may be accessed online [4].

Table 1: Wireless HD POV Recording System.

\begin{tabular}{|c|c|c|}
\hline Component & $\begin{array}{c}\text { Example of } \\
\text { Manufacturer }\end{array}$ & Cost (USD) \\
\hline POV Camera & GoPro & $\$ 600$ \\
\hline $\begin{array}{c}\text { Wireless HD } \\
\text { Transmission System }\end{array}$ & Nyrius & $\$ 200$ \\
\hline $\begin{array}{c}\text { USD Battery Power } \\
\text { Supply }\end{array}$ & Patriot & $\$ 50$ \\
\hline HD Capture System & Elgato & $\$ 200$ \\
\hline HD Monitor & Samsung & $\$ 400$ \\
\hline Laptop & Acer & $\$ 400$ \\
\hline Total Cost & & $\$ 1850$ \\
\hline
\end{tabular}




\section{Discussion}

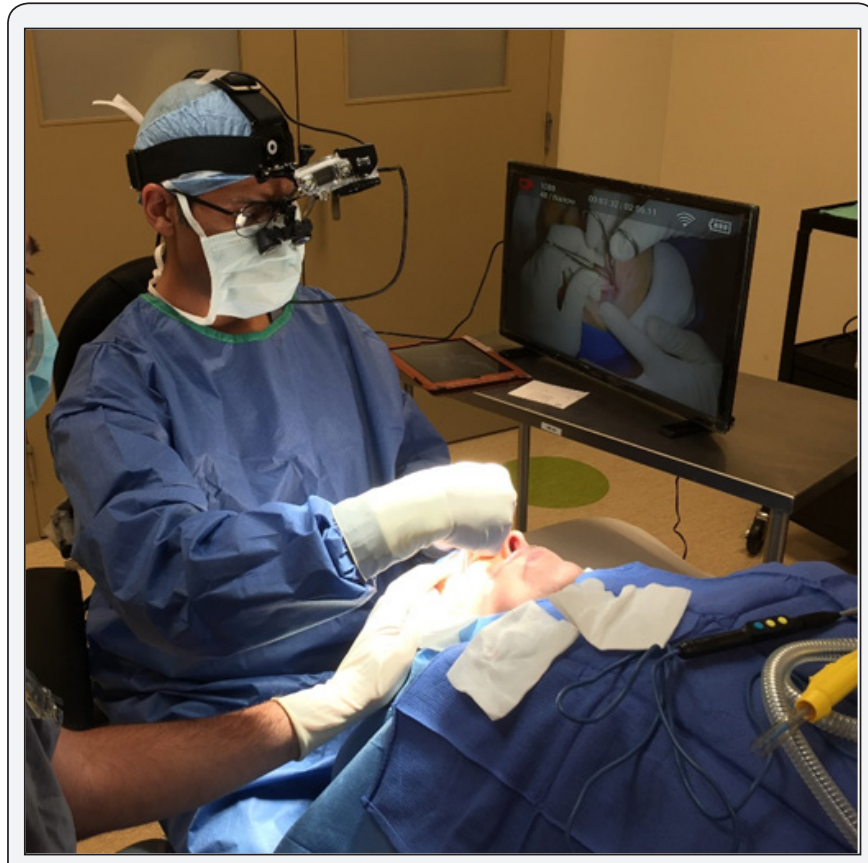

Figure 1: HD Wireless POV Camera on a headmount used to record oculoplastic surgery.

In a world where dedicated medical recording devices are expensive and impractical, and handheld smartphone recordings are of limited educational value, this described system is optimized for intuitive video recording. The system is cost-effective, scalable, and portable, allowing one to use a single system for multiple operating rooms. This system may also be used outside of the hospital in ambulatory clinics, humanitarian missions, and field hospitals. Finally, the wireless HD transmitting capability allows one to demonstrate live procedures to a large audience, allowing the surgical team to respond to questions in real time providing an exceptional educational tool.

\section{Conclusion}

Our system illustrates that a number of off-the-shelf consumer products may be combined to create a wireless, point of view HD surgical recording system that is accessible and costeffective.

\section{Conflict of Interest}

No conflicts of interest exist in the publication of this paper.

\section{References}

1. Gooi P, Ahmed Y, Ahmed II (2014) Use of a microscope-mounted wideangle point of view camera to record optimal hand position in ocular surgery. J Cataract Refractive Surgery 40(7): 1071-1074.

2. Warrian KJ, Kherani A, Gooi A, Gooi P (2014) Surgeons' point-of-view video recording technique for scleral buckling. Retina 34(10): 21512152.

3. Warrian KJ, Ashenhurst A, Gooi A, Gooi P (2015) A novel combination point-of-view (POV) action camera recording to capture the surgical field and instrument ergonomics in oculoplastic surgery. Ophthal Plastic \& Reconstructive Surg 31(4): 321-322.

4. Thompson A, Warrian K, Punja K, (2017) A cost effective wireless HD POV surgical recording system.

Your next submission with Juniper Publishers
will reach you the below assets
- Quality Editorial service
- Swift Peer Review
- Reprints availability
- E-prints Service
- Manuscript Podcast for convenient understanding
- Global attainment for your research
- Manuscript accessibility in different formats
( Pdf, E-pub, Full Text, Audio)
- Unceasing customer service
Track the below URL for one-step submission
https://juniperpublishers.com/online-submission.php

